\title{
TUHAN DAN ALAM PIKIRAN ANAK
}

Oleh Amir Syamsudin*)

Abstrak

Konsep ketuhanan pada anak sangat terkait erat dengan perkembangan moralitas anak. Perkembangan moralitas anak juga terkait erat dengan perkembangan kognitif anak. Semakin matang perkembangan kognitif anak, maka semakin matang pula perkembangan moralitas anak. Demikian pula semakin matang perkembangan moralitas anak, maka semakin jelas pula konsep ketuhanan dalam alam pikiran anak.

Tahap perkembangan kognitif anak usia 0-7 tahun adalah sensorimotor dan pra-operasional. Tahap perkembangan moral anak usia 0-7 tahun adalah pra-moral, tidak dapat membedakan baik dan buruk. Tahap perkembangan konsep ketuhanan pada anak usia 0-6 tahun bersifat kongkrit. Tahap perkembangan konsep ketuhanan pada anak usia 6-10 tahun bersifat personifikatif, yaitu orang dewasa dianggap sebagai tuhan karena ialah yang memberikan hukuman kepada anak yang nakal dan memberikan pujian kepada anak yang patuh.

Kata Kunci: alam pikiran anak, konsep ketuhanan, perkembangan kognitif, dan perkembangan moral.

\section{A. Pendahuluan}

Kadang terhenyak dengan pertanyaan tak terduga dari anak usia 6 tahun. "Ayah... ayah..., rumah Tuhan itu di mana?, apakah Tuhan itu laki-laki seperti ayah atau perempuan seperti ibu?". Apabila dijawab dengan menunjukkan telunjuk jari ke atas yang berarti Tuhan itu nun jauh di sana, maka anak bertanya lagi; "ayah... ayah... berarti burung dapat melihat Tuhan". Apabila dijawab Tuhan itu bukan laki-laki dan bukan perempuan, maka anak bertanya lagi; "ayah... ayah..., kalau begitu Tuhan itu banci".

Apa yang harus dilakukan orang tua atau guru untuk memuaskan rasa ingin tahu anak tanpa membuat anak frustasi dengan jawaban gaya orang dewasa? Kuncinya adalah orang dewasa (baca: orang tua dan guru) sebaiknya mengenali alam pikiran anak 
dan berusaha mengarahkan keingintahuan anak sesuai dengan cara pandang anak dalam membaca realitas.

Tulisan berikut akan menguraikan teori-teori perkembangan kognitif dan moral anak yang pernah dirumuskan oleh Jean Piaget dan Lawrence Kohlberg. Berdasarkan teori tersebut, diharapkan orang tua atau guru dapat belajar memahami alam pikiran anak dan menyampaikan konsep ketuhanan sesuai dengan alam pikiran anak.

\section{B. Tahapan Perkembangan Konsep Ketuhanan pada Anak}

Konsep ketuhanan pada anak sangat terkait erat dengan perkembangan moralitas anak. Perkembangan moralitas anak juga terkait erat dengan perkembangan kognitif anak. Semakin matang perkembangan kognitif anak, maka semakin matang pula perkembangan moralitas anak. Demikian pula semakin matang perkembangan moralitas anak, maka semakin jelas pula konsep ketuhanan dalam alam pikiran anak. Meskipun ada catatan bahwa tidak setiap anak yang mengalami kematangan perkembangan kognitif secara otomatis mengalami kematangan perkembangan moralitas, karena ada faktor lain yang mempengaruhinya (Heman Elia, 2000:1). Untuk menjelaskan tahapan perkembangan konsep ketuhanan pada anak, maka perlu dijelaskan terlebih dahulu tentang tahapan perkembangan kognitif maupun moralitas anak.

1. Perkembangan Kognitif \& Moralitas Anak menurut Jean Piaget (1896-1980)

\section{a. Empat Konsep Pokok Piaget}

Latar Belakang akademik Piaget ialah seorang Biolog, maka ia meyakini bahwa setiap makhluk hidup (termasuk manusia) perlu beradaptasi dan mengorganisasi lingkungan fisik di sekitarnya agar TETAP HIDUP. Pikiran dan tubuh manusia terkena aturan main yang sama, yaitu perlu beradaptasi dengan dan mengorganisasi lingkungan sekitar. Keempat 
konsep pokok tersebut ialah SKEMA, ASIMILASI, AKOMODASI, dan EQUILIBRATION.

Skema (bentuk tunggal) atau Skemata (bentuk jamak) adalah kemampuan kognitif seseorang untuk beradaptasi dan mengkoordinasikan lingkungan fisik sekitarnya. Skema/Skemata akan berubah dan berkembang sesuai dengan pengalaman hidup yang diperoleh. Contoh: Anak yang setiap hari melihat kucing di rumah, kemudian ia di bawa ke kebun binatang untuk melihat macan, maka ia akan menyebut macan tersebut "kucing besar".

Asimilasi adalah kemampuan kognitif seseorang untuk menempatkan dan mengklasifikasikan pengalaman baru dalam skema yang sudah dimilikinya. Asimilasi tidak merubah skema yang sudah ada, melainkan memperluas dan merinci cakupan skema yang sudah dimiliki. Contoh: Pengalaman anak melihat macan diasimilasikan dengan skema "kucing" yang sudah dimilikinya. Maka skema kucing diperluas dan terinci menjadi jenis-jenis kucing.

Akomodasi adalah kemampuan kognitif seseorang untuk menyusun skema baru, karena skema yang sudah dimilikinya tidak dapat menampung dan menggolongkan pengalaman baru yang dialaminya. Contoh: Anak melihat kucing atau macan dan menghitung jumlah kakinya. Kemudian ia melihat burung merpati, ternyata kakinya dua. Kemudian ia melihat ular, ternyata tanpa kaki. Kemudian ia melihat "luwing" (kaki seribu= bahasa Indonesia), ternyata kakinya banyak. Skema yang ada: semua binatang berkaki dua atau empat. Terjadi kebingungan, lalu berfikir, hasilnya Skema baru: ada binatang yang berkaki dan ada yang tidak berkaki; ada yang berkaki dua, empat, dan tak terhitung.

Equilibration adalah kemampuan kognitif seseorang untuk menyeimbangkan antara asimilasi dan akomodasi. 
Disequilibrium (kok ada binatang tidak berkaki), kemudian masuk ke tahap Equilibration (bingung, tanya, cari info, nguping, nginjen, lalu terinspirasi \{ingat bak mandi Archimides atau apel Einstein $\}$ ), dan akhirnya menjadi Equilibrium (ditemukan solusi). Equilibration merupakan proses menyatukan pengalaman baru dengan pengalaman lama (skema yang sudah dimilikinya).

Keempat konsep tersebut merupakan cara kerja pikiran dalam menanggapi pengalaman baru. Perkembangan cara kerja pikiran seiring sejalan dengan pertumbuhan fisik dan pertambahan usia kronologis anak. Bagaimana alam pikiran anak tentang REALITAS, khususnya tentang RUANG, BENDA, SEBAB AKIBAT, dan WAKTU? 


\section{b. Perkembangan Kognitif Anak}

Menurut Piaget, perkembangan alam pikiran anak melalui empat tahap perkembangan, yaitu sensorimotor, praoperasional, operasional kongkrit, operasional abstrak.

Sensorimotor (sejak lahir - 2 tahun) ditandai dengan anak sibuk memastikan hubungan tindakan yang dilakukan dengan akibat tindakan yang akan diperolehnya. Anak terus mencoba untuk memastikan bahwa tangan adalah bagian tubuhnya, sedangkan meja tempat tangannya bersandar adalah bukan bagian dari tubuhnya. Anak menyadari bahwa ada benda permanen di luar dirinya meskipun tidak terjangkau pancaindera.

Karakteristik tahapan ini ialah (1) membedakan diri sendiri dengan setiap objek; (2) mengenal diri sebagai pelaku kegiatan dan mulai bertindak dengan tujuan tertentu; (3) menguasai keadaan tetap dari objek.

Pra-operasional (2-7) ditandai dengan anak mulai menggunakan kata-kata untuk menunjuk benda. Satu objek dapat menjadi simbol bagi benda lain. Contoh: anak memperlakukan sebatang daun pisang seperti memperlakukan seekor kuda dan menungganginya. Kata-kata yang diucapkan anak dan imajinasinya belum diatur dengan cara yang logis. Keadaan ini disebut pra-operasional.

Karakteristik tahapan ini ialah (1) anak belajar menggunakan bahasa dan menggambarkan objek dengan imajinasi dan kata-kata; (2) berfikir egosentris; mengklasifikasi objek menurut tanda; (4) mulai memiliki kecakapan motorik.

Operasional Kongkrit (7-11) ditandai dengan anak dapat menguasai konsep konservasi. Contoh: anak mampu pulang dari sekolah ke rumah tanpa bantuan orang dewasa, tapi anak 
tidak mampu memetakan rute perjalanannya dari sekolah ke rumah dalam kertas.

Operasional Formal (11-15) ditandai dengan anak dapat berpikir logis dengan berbagai istilah simbolik murni. Anak sudah siap menjadi manusia dewasa dan menjalani kehidupan dengan kemampuannya sendiri.

c. Perkembangan Moral

Demikian pula perkembangan moral anak seiring dengan perkembangan kognitif anak. Bedanya perkembangan moral anak tahap pertama bertepatan dengan perkembangan kognitif tahap satu dan dua, sedangkan perkembangan moral anak tahap kedua bertepatan dengan perkembangan kognitif tahap tiga dan empat.

Anak usia 0-7 tahun belum dapat berpikir abstrak untuk membedakan baik dan buruk atau benar dan salah. Anak juga tidak terdorong untuk mengikuti peraturan, karena tidak tahu manfaat taat pada aturan. Anak hanya belajar bagaimana bertindak dalam situasi tertentu, bukan mengapa harus bertindak atau tidak bertindak.

Ingatan anak cenderung kurang baik, sehingga bagaimana berperilaku sosial yang baik memerlukan waktu yang panjang dan perlu kesungguhan dalam melakukannya. Anak tidak patuh pada aturan bukan karena ingin melawan lingkungan, melainkan karena lupa. Oleh karena itu perlu sering diingatkan. Piaget menyebut keadaan ini sebagai "moralitas oleh pembatasan" atau realisme moral.

Tahap perkembangan realisme moral ini bertepatan dengan tahapan pra-operasional dan operasional kongkrit perkembangan kognitif. Dalam tahap perkembangan moral ini, anak mengikuti peraturan tanpa berpikir dan menilai. Jika pun menilai benar atau salah, ukurannya berdasarkan akibat yang diterima anak sebagai reaksi orang dewasa atas perbuatan yang 
dilakukan anak. Anak beranggapan, perbuatan salah ialah tindakan yang mendapatkan hukuman. Hukuman dapat diberikan orang dewasa atau "tuhan"

Tahapan kedua dari perkembangan moral anak menurut Piaget ialah "moralitas oleh kerjasama atau hubungan timbal balik" atau moralitas otonomi. Tahap perkembangan moral otonomi ini bertepatan dengan tahapan operasional formal dalam perkembangan kognitif. Anak usai 7-11 tahun dapat menilai perbuatan atas dasar tujuan yang mendasarinya. Misalnya perbuatan berbohong, bagi anak usia 5 tahun dianggap selalu "buruk", tetapi bagi anak usia 12 tahun, berbohong dibenarkan dalam situasi tertentu.

2. Perkembangan Kognitif \& Moralitas Anak menurut L. Kohlberg (1927-1988)

\section{a. Metode Penelitian Moral Kohlberg}

Lawrence Kohlberg lahir tahun 1927 dan wafat pada 1988 di Amerika Serikat. Ia banyak mencurahkan tenaga dan waktu untuk mempelajari perkembangan moralitas dari sudut pandang psikologi. Ia bekerja di Universitas Chicago, kemudian pindah ke Universitas Harvard untuk memimpin lembaga Harvard's Center for Moral Education.

Kohlberg mengakui bahwa penelitiannya tentang moral sangat dipengaruhi oleh Jean Piaget (1896-1980). Kohlberg mengembangkan hasil penelitian Piaget tentang moral anak dengan dua cara. Pertama, dalam penelitian tentang moral, Kohlberg tidak membatasi perkembangan moral pada anak saja, melainkan ia mengamati perkembangan moral anak secara berkesinambungan semenjak usia 6 tahun sampai dengan 28 tahun. Kedua, Kohlberg memperluas cakrawala kebudayaan tentang subjek penelitiannya dengan cara mengikutsertakan subjek penelitian lain di luar kebudayaan 
Amerika Serikat. Kebudayaan lain tersebut ialah Malaysia, Taiwan, Mexico dan Turki. Kohlberg yakin bahwa hasil penelitiannya berlaku untuk lintas budaya dan tidak terbatas pada kebudayaan Amerika Serikat saja.

Metode penelitian moral yang dipakai Kohlberg ialah mengajukan pertanyaan moral yang bersifat dilematis dan khayalan kepada subjek penelitiannya. Dilematis artinya pilihan moral yang sulit dibedakan baik buruknya seperti "pepatah" buah simalakama: bila berdusta nyawa seorang kawan selamat, bila terus terang terjadi prahara terhadap kawan kita. Khayalan artinya dilema moral itu diambil bukan berasal dari kasus kongkrit tetapi dari kemungkinan dapat terjadi dalam kenyataan.

Contoh dilema moral bersifat khayalan: Seorang anak ingin memelihara ikan, tetapi sang anak tidak tahu jenis makanan yang disukai ikan tersebut. Dilema moral: apakah ikan tersebut akan dipelihara dan mati kelaparan atau dilepas ke sungai agar ia dapat mencari makan sendiri? Khayalan: karena saat ini tidak terjadi dalam kehidupan anak, tetapi mungkin terjadi dalam kehidupan anak di masa yang akan datang.

Dengan Metode Dilema Moral ini Kohlberg bermaksud menggali jawaban atas dua pertanyaan penelitian yang ia ajukan. Pertama, bagaimana anak-anak memecahkan dilema moral tersebut? Kedua, apa alasan yang diberikan anak-anak atas keputusan moral yang dipilihnya.

Contoh: anak diminta orang tuanya berkata "tidak ada" kepada tamu yang akan berkunjung, padahal anak tahu orang tuanya berada di rumah. Pertanyaan pertama akan dijawab oleh anak bahwa permintaan orang tuanya tersebut termasuk berbohong. Pertanyaan kedua akan dijawab berbeda oleh masing-masing anak. Anak 1: saya pilih berbohong karena takut dihukum oleh orang tua. Anak 2: saya pilih berbohong 
karena ingin melindungi kedua orang tua. Anak 3: saya pilih berbohong karena ingin diberi uang jajan oleh orang tua.

Contoh yang dipakai Kohlberg adalah Dilema Apoteker Heinz sebagai berikut:

"Heinz Mencuri Obat di Eropa"
Seorang perempuan sudah hampir meninggal dunia akibat semacam kanker. Ada suatu obat
yang menurut dokter dapat menyelamatkannya. Obat itu adalah semacam radium yang baru
saja ditemukan oleh seorang apoteker di kota yang sama. Obat itu mahal ongkos
pembuatannya, tetapi si apoteker menjualnya sepuluh kali lipat ongkos pembuatannya
tersebut. Ia membayar $\$ 200$ untuk radium tersebut dan menjualnya $\$ 2.000$ untuk satu
dosis kecil obat tersebut. Suami dari perempuan yang sakit, Heinz, pergi ke setiap orang
yang dia kenal untuk meminjam uang, tapi ia cuma memperoleh $\$ 1.000$, setengah dari
harga obat seharusnya. Ia berceritera kepada apoteker bahwa isterinya sudah sekarat dan
memintanya untuk dapat menjual obat dengan lebih murah atau memperbolehkan dia
melunasinya di kemudian hari. Tetapi si apoteker mengatakan: "Tidak, saya yang
menemukan obat itu dan saya akan mencari uang dari obat itu." Heinz menjadi putus asa
dan membongkar apotek tersebut untuk mencuri obat demi istrinya (Wikipedia, 19
September 2007).

Haruskah Heinz membongkar apotek itu untuk mencuri obat bagi isterinya? Mengapa? Dari sudut pandang teoretis, apa yang menurut partisipan perlu dilakukan oleh Heinz tidaklah penting. Teori Kohlberg berpendapat bahwa justifikasi yang diberikan oleh partisipanlah yang signifikan, bentuk dari respon mereka.

\section{b. Hasil Penelitian Kohlberg}

Berdasarkan teori perkembangan kognitif Piaget yang sudah diadaptasi sesuai dengan kerangka berfikirnya, Kohlberg merumuskan teori perkembangan moral sebagai berikut:

\begin{tabular}{|c|c|c|}
\hline Usia Kronologis & Tahap Perkembangan & Perasaan \\
\hline $\begin{array}{l}\text { Pra-moral } \\
0-6 \text { th }\end{array}$ & $\begin{array}{l}\text { TAHAP 0: Anak belum dapat membedakan baik dan } \\
\text { buruk }\end{array}$ & Belum diamati \\
\hline \multirow[t]{2}{*}{$\begin{array}{l}\text { Pra-konvensional } \\
6-10 \text { th }\end{array}$} & $\begin{array}{l}\text { TAHAP 1: Anak menilai baik-buruk berdasarkan } \\
\text { akibat perbuatan }\end{array}$ & \multirow{2}{*}{$\begin{array}{l}\text { Takut akan } \\
\text { akibat negatif } \\
\text { perbuatan }\end{array}$} \\
\hline & $\begin{array}{l}\text { TAHAP 2: Anak menilai baik-buruk berdasarkan } \\
\text { kontrak/imbal jasa }\end{array}$ & \\
\hline \multirow[t]{2}{*}{$\begin{array}{l}\text { Konvensional } \\
10-17 \text { th }\end{array}$} & $\begin{array}{l}\text { TAHAP 3: Orang menilai baik-buruk berdasarkan } \\
\text { persetujuan orang lain }\end{array}$ & \multirow{2}{*}{$\begin{array}{l}\text { Rasa bersalah } \\
\text { bila berbeda } \\
\text { dari orang lain }\end{array}$} \\
\hline & $\begin{array}{l}\text { TAHAP 4: Orang menilai baik-buruk berdasarkan } \\
\text { ketertiban sosial }\end{array}$ & \\
\hline \multirow{2}{*}{$\begin{array}{l}\text { Pasca- } \\
\text { konvensional } \\
17-28 \text { th }\end{array}$} & $\begin{array}{l}\text { TAHAP 5: Orang menilai baik-buruk berdasarkan } \\
\text { hukum yang berlaku }\end{array}$ & \multirow{2}{*}{$\begin{array}{l}\text { Penyesalan dan } \\
\text { menyalahkan } \\
\text { diri sendiri }\end{array}$} \\
\hline & $\begin{array}{l}\text { TAHAP 6: Orang menilai baik-buruk berdasarkan } \\
\text { hati nurani }\end{array}$ & \\
\hline
\end{tabular}


Pra-moral: anak belum dapat membedakan baik dan buruk. Pra-konvensional: anak mulai dapat membedakan baik dan buruk berdasarkan reaksi orang lain atas perbuatannya. Tingkat ini mengandung dua tahap, yaitu (1) tahap hukuman \& kepatuhan dan (2) tahap instrumental. Contoh tahap 1: seorang anak tidak mencubit adik yang sedang diasuhnya karena takut mendapat hukuman dari ibu.

Instrumental artinya anak menilai perbuatan itu baik jika berguna untuk memenuhi kepentingannya sendiri dan juga kepentingan orang lain. Contoh tahap 2: anak berbagi makanan dengan temannya karena berharap satu saat temannya tersebut juga akan berbagi makanan dengan dia.

Konvensional: anak mulai menyesuaikan penilaian dan perbuatannya dengan harapan orang lain dan atau peraturan kelompok. Anak loyal dan mendukung nilai moral yang berlaku pada kelompok sosialnya tersebut. Tingkat ini juga mengandung dua tahap, yaitu (3) tahap menjadi anak manis dan (4) tahap taat pada hukum.

Contoh tahap 3: memecahkan gelas ketika membantu ibu mencuci alat rumah tangga tidak dianggap buruk, karena "wajah cemberut" orang tua tanda cemas akan keselamatan anaknya. Perbuatan itu baik jika menyenangkan dan disetujui oleh orang lain.

Contoh tahap 4: orang mentaati peraturan lalu lintas bukan karena takut "diupeti" oleh polisi melainkan karena ingin selamat dalam perjalanan dan tidak membahayakan orang lain.

Pasca-konvensional: anak muda menilai bahwa nilai moral yang dianut masyarakatnya tidak selalu harus ditaati. Adakalanya ia harus mengatakan "tidak" terhadap nilai moral masyarakatnya. Tingkat ini mengandung dua tahap, yaitu (5) 
tahap persetujuan bebas dan perjanjian dan (6) tahap hati nurani.

Persetujuan bebas dan perjanjian artinya anak muda menepati isi perjanjian yang telah dibuatnya secara sadar dan bebas, meskipun isi perjanjian tersebut berakibat merugikan dirinya sendiri. Contoh tahap 5: sudah berjanji hari ini pukul 13.30 saya akan menghadiri undangan teman, meskipun hujan deras, ban sepeda motor gembos, tidak punya uang untuk beli bensin, tetap saya berusaha datang dengan cara apapun yang dapat saya lakukan.

Hati nurani artinya orang berbuat baik karena perbuatan tersebut memang baik dan tidak menuntut pamrih apapun. Contoh tahap 6: seorang guru TK, di akhir bulan hanya memiliki persediaan logistik keluarganya untuk 2 hari ke depan, tetapi ia rela memberikan jatah logistiknya tersebut untuk menyelamatkan tetangganya yang hampir mati kelaparan, bukan karena ingin pujian atau imbalan, tetapi karena kehidupan harus dilestarikan.

Setiap anak akan melalui tahap perkembangan moral, mulai dari pra-moral, pra-konvensional, konvensional, sampai dengan pasca-konvensional. Meskipun tidak selalu bertambahnya usia anak juga menyebabkan berpindahnya tahap perkembangan moral ke yang lebih tinggi. Setiap anak hanya dapat mengerti penalaran moral satu tahap di atas tahap di mana ia berada. Setiap anak akan tertarik pada cara berfikir satu tahap lebih tinggi dari tahapan berpikirnya sendiri.

Oleh karena itu, dalam proses pendidikan moral, sebaiknya dicampur antara anak kecil dan anak besar. Setiap anak akan mengalami perkembangan moral jika ia mengalami ketidakseimbangan kognitif dalam penilaian moral yang dilakukannya. Tahap keenam dari perkembangan moral sebaiknya menjadi tujuan dari pendidikan. 


\section{Tuhan dalam Alam Pikiran Anak}

Dari dua teori perkembangan kognitif dan moral di atas jelas sekali bahwa anak usia 0-7 tahun belum mampu berfikir abstrak. Perkembangan kognitifnya masih sensorimotor/praoperasional. Demikian pula perkembangan moralnya masih dalam tahap pra-moral, sehingga anak belum dapat membedakan baik dan buruk, apalagi mengenal siapa Tuhan. Ringkasnya, anak usia dini memiliki konsep ketuhanan yang bersifat kongkrit dan tidak memiliki konsep tentang tuhan yang abstrak seperti konsep ketuhanan yang dimiliki oleh orang dewasa. Berikut contoh alam pikiran anak tentang Tuhan:

Ketika anakku ingin mengenal Allah
(By Nilna on August 8th, 2007, Posted in Ekspresi, oleh: Yogas Wati)
Ketika itu, akhir Desember 2001. Sebuah perjalanan berharga kami
lakukan. Tias, anakku semata wayang yang lahir di Bandung dan besar di
Jakarta, melakukan perjalanan panjang pertamanya. Waktu itu umurnya 3
tahun 10 bulan dan saat itu kami mau balik ke Aceh (Lhokseumawe), setelah
si Abah selama 5 tahun menyelesaikan masa penugasannya di Jakarta (tapi
sejak pertengahan 2005 kami telah pulang kampung kembali ke Bandung,
dan entah mau merantau ke mana lagi).
Mau naik pesawat untuk yang pertama kali ia senaaang sekali. Sepanjang
perjalanan dari rumah hingga di bandara, saat menunggu pemberangkatan,
ia senantiasa bernyanyi-nyanyi, dan asyik main sendiri, mengeksplorasi
lingkungan sekitar sambil terlihat mengobrol sendiri, memainkan jari, duduk
dipojok sana-sini, tenggelam dalam imajinasi. Kami hanya mengawasi dari
kejauhan sambil merasakan kegembiraan yang ia rasakan.
Di pesawat, ia memilih tempat dekat jendela. Ketika pesawat berada di
tengah bongkahan awan, yang bak salju berwarna putih abu keperakan
ditimpa cahaya matahari pagi, kadang juga terkesan seperti hamparan kapas
yang membentuk gerombol-gerombol raksasa seperti bunga kol. Di
sebagiannya seperti menampakkan gua-gua dan di sebagiannya menghampar
luas tak berbatas, bak Padang Mahsyar? sungguh menakjubkan.
Hening, kami tenggelam dalam imajinasi masing-masing. Dalam hati, tiap
memandangi kehebatan pemandangan awan ini, saya berdzikir.. Subhanallah
Walhamdulillah Walaaailaaha Illallah Wallaahu Akbar. Tiba-tiba, Tias
mengagetkanku, dengan pertanyaan, "Bu..., di awan sana ada Allah ya?!". Iya,
jawabku. "Ada malaikat-malaikat juga ya Bu?!" Iya, jawabku lagi, pendek,
sambil bergumam dalam hati, "Tias, kamu juga ngerasain ya, melihat
pemandangan yang menakjubkan ini jadi teringat Allah".
Selagi pikiranku menerawang begitu, ia berceloteh lagi, "Bu, kalau Allah
ditembak Ia pasti jatuh ya!!" Hah..., aku agak terperanjat. "Ya, nggaklah!"
kataku. "Allah itu Maha Hebat, mana ada dia bisa jatuh ditembak!" "Iya...!.."


katanya. "Tidaklah Nak" jawabku lagi, tidak kreatif. “Ah, iya, pasti Jatuh..!!" anakku mempertahankan logika pemikirannya. Ah, otakku ini memang tumpul, dikagetkan dengan pertanyaan mendadak seperti begini aku belum bisa menjawabnya. Lagi pula akupun cape, dan ngantuuk sekali, lagi malas memeras pikiran untuk ngejelas-jelasin. Jadi aku abaikan saja...

Beberapa bulan kemudian, Tias berusia sekitar 4 tahun 2 bulan, ketika kami sedang bermain bersama di rumah, ia mengajukan lagi pertanyaan tentang Allah. Tanyanya, "Bu Allah, itu matanya banyak ya..." Ya nggaklah, jawabku lagi-lagi tergagap. "Kan Allah bisa melihat dimana-mana," sambung anakku cepat. "Iya, Allah memang Maha Melihat, Ia bisa tahu keadaan yang ada di Bandung, di kantor Abah, di rumah kita, dll, tapi mata Allah nggak kaya mata kita manusia.." jawabku sekenanya.

Sejujurnya aku cukup bingung, belum rajin baca-baca literatur "Bab menerangkan keberadaan Allah pada Anak". "Kepala Allah itu pasti besaaar sekali ya Bu!" lagi-lagi anakku mengeluarkan stigma-stigma yang sedang berseliweran di pemikirannya.

Tawaku hampir meledak, geli, membayangkan bagaimana ia membayangkan. Tapi, Oh...lagi-lagi pikiranku tumpul, gak siap dengan pertanyaan-pertanyaan begini dari anakku. dan aku hanya menjawab, dengan bantahan yang itu-itu juga, "Ya nggaklah, Allah tidak berkepala seperti kita....Allah itu berbeda dengan kita. Ia tidak bisa dibayangkan dan tidak bisa dilihat oleh mata kita."

Anakku tampak bingung, aku melanjutkan lagi, "Nah seperti angin...Nih... (aku meniupnya). Adakan?" tanyaku. Tias mengangguk, "Tapi gak kelihatan kan?!" tanyaku lagi kepadanya. Tias diam. "Jadi Allah juga seperti itu, Dia ada, tapi tak bisa dilihat." "Allah itu laki-laki apa perempuan Bu?" tanya anakku tampaknya masih penasaran. "Ya Allah itu gak laki-laki, gak perempuan. Yang ada jenis kelaminnya itu kan hanya kita manusia yang Allah ciptakan, tapi Allah sendiri mah yang menciptakan kita, gak berjenis kelamin" (padahal aku juga ragu arti jenis kelamin bila dikaitkan dengan mudzakar - muannasnya kata yang digunakan dalam Al-Qur'an. Tak tahulah ilmuku juga sangat terbatas)

Tias cemberut. Aku mencoba mencari penjelasan tambahan, "Adakan di dunia ini juga yang tidak berjenis kelamin. Coba kamu perhatikan hayoo... tembok, kursi, .. dia laki-laki apa perempuan ? nggak kan? Nah jadi Allah juga begitu, Ia tidak berjenis kelamin..."

Belum lagi aku dapat menemukan kata-kata lengkap yang dapat menjawab kepenasaran pikiran anakku, ia telah menungkas dengan nada tinggi, kesal dan mungkin marah, "Tahulah, Tias! Allah itu jelek! Nggak punya mata, nggak punya kepala!!!” Aku terdiam. Aku terperangah. Tapi aku sadar, ia kecewa dengan jawaban-jawabanku.

Betapa kecewanya anakku, menerima jawaban-jawabanku, yang tak dapat ia susun ke dalam pengertiannya menjadi sebuah penjelasan utuh yang menerangkan. Aku beristighfar di dalam hati, "Ya Allah, maafkanlah kami. Maafkanlah anakku yang telah melontarkan kata-kata kasar terhadap-Mu karena ketidaktahuannya. Dan ampunilah hamba yang tidak dapat memberikan penjelasan yang menunjukkan kebenaran-Mu kepadanya". Aku amat sedih sekali. Kasihan melihat kekecewaan anakku yang tidak mendapat kepuasaan tentang "Sosok Allah" yang ia coba ingin kenali. Dan aku kecewa kepada diriku sendiri yang belum mampu memberinya penjelasan yang bisa ia fahami. 


\section{Penutup}

Tahap perkembangan kognitif anak usia 0-7 tahun adalah sensorimotor dan pra-operasional. Tahap perkembangan moral anak usia 0-7 tahun adalah pra-moral, tidak dapat membedakan baik dan buruk. Tahap perkembangan konsep ketuhanan pada anak usia 0-6 tahun bersifat kongkrit. Tahap perkembangan konsep ketuhanan pada anak usia 6-10 tahun bersifat personifikatif, yaitu orang dewasa dianggap sebagai tuhan karena ialah yang memberikan hukuman kepada anak yang nakal dan memberikan pujian kepada anak yang patuh. Tahap perkembangan konsep ketuhanan pada anak usia 10 tahun ke atas bersifat abstrak.

Ringkasan perkembangan moral manusia semenjak usia 6-28 tahun menurut Kohlberg adalah sebagai berikut:

\begin{tabular}{|c|c|c|c|c|c|}
\hline \multicolumn{2}{|c|}{ Pra-Konvesional } & \multicolumn{2}{|c|}{ Konvensional } & \multicolumn{2}{|c|}{ Pasca-Konvensional } \\
\hline $\begin{array}{l}\text { Kepatuhan } \\
\text { dan } \\
\text { Hukuman }\end{array}$ & $\begin{array}{l}\text { Minat } \\
\text { pribadi (apa } \\
\text { untungnya } \\
\text { buat saya?) }\end{array}$ & $\begin{array}{l}\text { Keserasian } \\
\text { interpersonal } \\
\text { dan } \\
\text { konformitas }\end{array}$ & $\begin{array}{l}\text { Otoritas dan } \\
\text { pemeliharaan } \\
\text { aturan sosial }\end{array}$ & $\begin{array}{l}\text { Kontrak } \\
\text { sosial }\end{array}$ & $\begin{array}{l}\text { Prinsip etika } \\
\text { universal }\end{array}$ \\
\hline $\begin{array}{l}\text { Ukuran baik } \\
\text { dan buruk } \\
\text { adalah akibat } \\
\text { langsung dari } \\
\text { perbuatan }\end{array}$ & $\begin{array}{l}\text { Ukuran } \\
\text { baik dan } \\
\text { buruk } \\
\text { adalah } \\
\text { keuntungan } \\
\text { yang } \\
\text { diperoleh }\end{array}$ & $\begin{array}{l}\text { Ukuran baik } \\
\text { dan buruk } \\
\text { adalah } \\
\text { memenuhi } \\
\text { harapan orang } \\
\text { banyak atau } \\
\text { tidak }\end{array}$ & $\begin{array}{l}\text { Ukuran baik } \\
\text { dan buruk } \\
\text { adalah } \\
\text { berguna bagi } \\
\text { keutuhan } \\
\text { dan } \\
\text { keamanan } \\
\text { masyarakat }\end{array}$ & $\begin{array}{l}\text { Ukuran baik } \\
\text { dan buruk } \\
\text { adalah } \\
\text { kebermanfaatan } \\
\text { bagi semua } \\
\text { orang }\end{array}$ & $\begin{array}{l}\text { Ukuran baik } \\
\text { dan buruk } \\
\text { adalah } \\
\text { keadilan }\end{array}$ \\
\hline $\begin{array}{l}\text { Perbuatan itu } \\
\text { salah jika } \\
\text { pelakunya } \\
\text { dihukum. } \\
\text { Semakin } \\
\text { keras } \\
\text { hukuman } \\
\text { diberikan itu } \\
\text { berarti bobot } \\
\text { kesalahannya } \\
\text { berat }\end{array}$ & $\begin{array}{l}\text { Perbuatan } \\
\text { itu baik jika } \\
\text { memberikan } \\
\text { keuntungan } \\
\text { sebanyak- } \\
\text { banyaknya. }\end{array}$ & $\begin{array}{l}\text { Perbuatan itu } \\
\text { baik jika } \\
\text { memenuhi } \\
\text { harapan } \\
\text { teman, } \\
\text { keluarga, atau } \\
\text { masyarakatnya }\end{array}$ & $\begin{array}{l}\text { Perbuatan } \\
\text { itu baik jika } \\
\text { bermanfaat } \\
\text { bagi } \\
\text { keutuhan } \\
\text { komunitas } \\
\text { sosial tempat } \\
\text { ia bermukim }\end{array}$ & $\begin{array}{l}\text { Perbuatan itu } \\
\text { baik jika } \\
\text { memenuhi } \\
\text { aturan sosial } \\
\text { yang disepakati, } \\
\text { dan aturan } \\
\text { sosial itu baik } \\
\text { jika disepakati } \\
\text { bersama }\end{array}$ & $\begin{array}{l}\text { Perbuatan } \\
\text { itu baik jika } \\
\text { adil dan } \\
\text { motivasinya } \\
\text { bersifat } \\
\text { intrinsik, } \\
\text { bukan } \\
\text { karena } \\
\text { minat } \\
\text { pribadi, } \\
\text { memenuhi } \\
\text { harapan } \\
\text { orang lain, } \\
\text { legal, atau } \\
\text { kesepakatan. }\end{array}$ \\
\hline
\end{tabular}




\section{Daftar Pustaka}

Elizabeth B. Hurlock.2005. Perkembangan Anak, Jilid 2. Jakarta: Erlangga.

Elizabeth B. Hurlock. 2004. Psikologi Perkembangan. Jakarta: Erlangga.

K. Bertens, 1994. Etika. Jakarta: Gramedia. Hal.78-87.

Heman Elia. 2000. Moralitas anak berkembang dari waktu ke waktu. Dalam EUNIKA: buletin pendidikan iman anak. (online). http://www.geocities.com/ eunikanet/21/kembang.html.

Pam Schiller \& Tamera Bryant, 2002, 16 Moral Dasar Bagi Anak, Jakarta: Elex Media Komputindo.

Rita L. Atkinson. 1991. Pengantar Psikologi. Jakarta: Erlangga.

Siti Rahayu Haditono, dkk. 2004. Psikologi Perkembangan. Yogyakarta: Gadjah Mada University Press. Cetakan Kelimabelas.

\footnotetext{
*) Amir Syamsudin adalah dosen Pendidikan Agama Islam di Universitas Negeri Yogyakarta. Ia menyelesaikan studi strata satu (S-1) Jurusan Aqidah \& Filsafat, Fakultas Ushuluddin, IAIN Sunan Kalijaga Yogyakarta pada tahun 1997. Strata dua (S-2) Program Studi Agama \& Filsafat, Konsentrasi Filsafat Islam di IAIN Sunan Kalijaga Yogyakarta lulus tahun 1999. Mulai tahun akademik 2008-2009 melanjutkan studi strata 3 (S-3) Penelitian dan Evaluasi Pendidikan (PEP) UNY. Ia bekerja di UNY sejak 1 Maret 1999 sampai sekarang. Pada 2004, ia bergabung dengan program studi D-II Pendidikan Guru Taman Kanak-kanak (PGTK), Fakultas Ilmu Pendidikan, Universitas Negeri Yogyakarta untuk mengampu mata kuliah "Metode Pengembangan Moral dan Nilai-nilai Keagamaan". Pada 2006, menjadi Ketua Tim Penyiapan Proposal Pembukaan Program Studi S-1 Pendidikan Guru Pendidikan Anak Usia Dini (PG-PAUD), Jurusan Pendidikan Pra-sekolah \& Sekolah Dasar (PPSD), Fakultas Ilmu Pendidikan, Universitas Negeri Yogyakarta. Pada 2007, menjadi Ketua Pelaksana Program Hibah Kompetisi (PHK) PGSD-A Batch I Tahun Anggaran 2007.
} 